\title{
Antiproliferative Activity of Steroidal Oxime and its 0 -Alkylated Derivatives
}

\author{
Jovana Ajduković ${ }^{1 *}$, Marija Filipović ${ }^{1}$, Milana Perković ${ }^{1}$, Elizabeta Stanić ${ }^{1}$, Dimitar Jakimov ${ }^{2}$ \\ ${ }^{1}$ Department of Chemistry, Biochemistry and Environmental Protection, Faculty of \\ Sciences, University of Novi Sad, Trg Dositeja Obradovića 3, 21000 Novi Sad, Serbia. \\ ${ }^{2}$ Oncology Institute of Vojvodina, Faculty of Medicine, University of Novi Sad, Put \\ Dr Goldmana 4, 21204 Sremska Kamenica, Serbia \\ *Corresponding author: jovana.ajdukovic@dh.uns.ac.rs
}

\section{- Introduction}

The heterosteroids are of great pharmaceutical importance because of their diverse biological activities. Oxime ethers have attracted much interest as important precursors and intermediates for the preparation of a wide variety of drugs and natural products. They can be easily converted into important functional groups such as amino alcohols and hydroxy ketones. Therefore, the development of methodologies for the preparation of oxime ethers is of considerable interest. Various researchers have studied the interesting biological properties of oxime ether derivatives such as anticonvulsant, anti-inflammatory, antineoplastic, antienteroviral, antimicrobial, antitumor, and anti-Helicobacter pylori activities [1].

Since clinical use of almost all anticancer drugs has been limited by the toxicity to normal tissues, important goal of cancer chemotherapy is to amplify the selective inhibition of tumor cells while decreasing toxicity to normal tissues.

In our previous papers [2-4] we have described the synthesis of a series of 17-substituted androstane derivatives with strong activity against selected tumor cell lines.

\section{- Results and Discussion}

Searching for a new steroidal citotoxic agents that could be applied against different hormone-dependent and independent diseases, we have synthesized a new 17-picolinylidene androstane derivatives, that besides heterocyclic substituent at C-17, possess free and $O$-alkylated hidroxyimino group. Therefore, in order to obtain a new heterosteroids, compound 1 was, in several synthetic steps, transformed to 3(E)-hydroxyimino derivative 6, which was then treated with two different hydrochlorides of dialkylamino ethyl chlorides in basic conditions, giving oxime ethers 8 and $\mathbf{9}$ (Scheme 1). New compounds were screened for antiproliferative activity $\left(\mathrm{IC}_{50}, \mu \mathrm{M}\right)$ against three tumor cell lines, as well as one human non-tumor cells, after $72 \mathrm{~h}$ using the standard $\mathrm{MTT}$ assay.

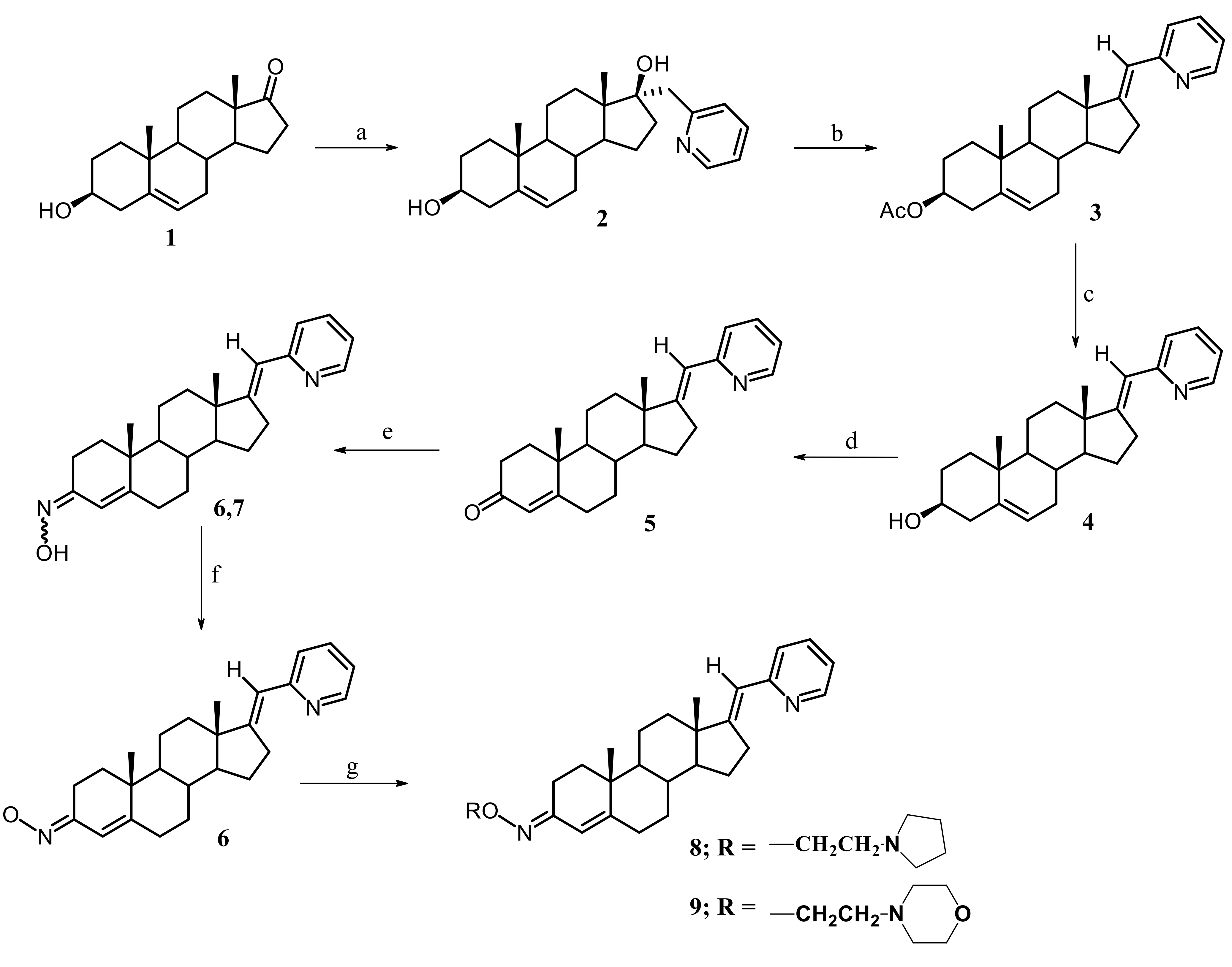

Scheme 1. a) $\alpha-P y \mathrm{CH}_{2} \mathrm{Li}, \mathrm{THF}$, r.t., $6 \mathrm{~h} ; \mathrm{H}_{2} \mathrm{O}$; b) $\mathrm{Ac}_{2} \mathrm{O}$, reflux, $6 \mathrm{~h}$; c) $\mathrm{KOH}, \mathrm{MeOH}$, reflux, $1 \mathrm{~h}$; d) cyclohexanone, $\mathrm{Al}(\mathrm{i}-\mathrm{PrO})_{3}$, toluene, co-distillation, 2h; e) $\mathrm{NH}_{2} \mathrm{OH} \cdot \mathrm{HCl}, \mathrm{AcONa}, 95 \% \mathrm{EtOH}$, reflux, $1.5 \mathrm{~h}$ f) chromatographic separation of $E$ and $Z$ isomers; g) $\mathrm{R}-\mathrm{Cl} \cdot \mathrm{HCl}, \mathrm{KOH}, \mathrm{K}_{2} \mathrm{CO}_{3}$, butanone, r.t.

\begin{tabular}{|c|c|c|c|c|}
\hline Compound & MDA-MB-231 & HeLa & HT-29 & MRC-5 \\
\hline 6 & 47.3 & $>100$ & 4.4 & $>100$ \\
\hline 8 & 4.7 & 22.6 & 3.2 & $>100$ \\
\hline 9 & 26.8 & 44.1 & 7.8 & $>100$ \\
\hline Doxorubicin & 0.12 & 0.07 & 0.15 & 0.12 \\
\hline
\end{tabular}

MDA-MB-231 - breast adenocarcinoma ER-

HeLa - human cervical carcinoma

HT-29 - colon adenocarcinoma

MRC-5 - normal fetal lung fibroblast

\section{- Conclusion}

All three compounds, $\mathbf{6 , 8}$ and $\mathbf{9}$ showed a markedly strong cytotoxicity against HT-29 cancer cells, wherein compound 8 also exibited significant activity against MDA-MB-231 cancer cells. Results were compared with the non-selective cytotoxic drug doxorubicin (DOX). It is important to note that all steroidal compounds were non-toxic to healthy MRC- 5 cells, unlike the doxorubicin.

It can be concluded that these androstane derivatives represent promising candidates for the development of new steroid-based compounds for the treatment of prostate cancer, indicating the need for more detailed future studies.

\section{- References}

[1] K. Sharma, S. B. Mishra, A. K. Mishra, Helv. Chim. Acta 94 (2011), 2256.

[2] J. Ajduković, E. Djurendić, E. Petri, O. Klisurić, A. Ćelić, M. Sakač, D. Jakimov, K. Penov Gaši, Bioorg. Med. Chem. 21 (2013), 7257.

[3] E. Djurendić, J. Ajduković, M. Sakač, J. Csanádi, V. Kojić, G. Bogdanović, K. Penov Gaši, Eur. J. Med. Chem. 54 (2012), 784.

[4] J. J. Ajduković, K. M. Penov Gaši, D. S. Jakimov, O. R. Klisuric, S. S. Jovanovic-Šanta, M. N. Sakac, L. D. Aleksic, E. A. Djurendic, Bioorg. Med. Chem. 23 (2015), 1557.

Acknowledgements: This work was financialy supported by Ministry of Education, Science and Technological development of the Republic of Serbia (Project No. 172021). 